\title{
Phenotypic and Genotypic Characterization of Atypical Lactococcus garvieae Strains Isolated from Water Buffalos with Subclinical Mastitis and Confirmation of L. garvieae as a Senior Subjective Synonym of Enterococcus seriolicida
}

\author{
LÚCIA M. TEIXEIRA, ${ }^{1,2 *}$ VÂNIA LÚCIA C. MERQUIOR,,$^{1,3}$ MARIA DA CONCEIÇÃO E. VIANNI, ${ }^{1,4}$ \\ MARIA DA GLÓRIA S. CARVALHO ${ }^{1}$ SÉRGIO E. L. FRACALANZZA, ${ }^{1}$ \\ ARNOLD G. STEIGERWALT, ${ }^{2}$ DON J. BRENNER, ${ }^{2}$ \\ AND RICHARD R. FACKLAM ${ }^{2}$
}

Instituto de Microbiologia, Universidade Federal do Rio de Janeiro, Rio de Janeiro 21941, ${ }^{1}$ Faculdade de Ciências Médicas, Universidade do Estado do Rio de Janeiro, Rio de Janeiro 20551, ${ }^{3}$ and Instituto de Veterinária, Universidade Federal Rural do Rio de Janeiro, Seropédica $23851,{ }^{4}$ Brazil, and Division of Bacterial and Mycotic Diseases, National Center for Infectious Diseases, Centers for Disease Control and Prevention, Atlanta, Georgia $30333^{2}$

\begin{abstract}
During a survey of bacterial agents that cause subclinical mastitis in water buffalos, we isolated several strains of gram-positive cocci that appeared to be enterococci except that they grew very slowly at $45^{\circ} \mathrm{C}$ and grew slowly in broth containing $6.5 \% \mathrm{NaCl}$. On the basis of the results of conventional physiologic tests, these strains were identified as Enterococcus durans. However, none of the strains reacted with the AccuProbe Enterococcus genetic probe. The whole-cell protein profiles of these organisms were compared with the profiles of Enterococcus and Lactococcus reference strains. Apart from minor quantitative differences, the mastitis isolates had indistinguishable protein profiles that were similar to the profiles of the Lactococcus garvieae and Enterococcus seriolicida type strains. The results of DNA relatedness studies performed by using the hydroxyapatite method at 55 and $70^{\circ} \mathrm{C}$ indicated that all of the mastitis isolates were related to the type strain of $L$. garvieae at the species level, despite the fact that they exhibited several uncommon phenotypic characteristics (growth at $45^{\circ} \mathrm{C}$, growth in broth containing $6.5 \% \mathrm{NaCl}$, and failure to produce acid from mannitol and sucrose). The high levels of DNA relatedness between strains of $L$. garvieae and $E$. seriolicida demonstrated that these taxa are members of a single species. Since $L$. garvieae is a senior synonym of $E$. seriolicida, $L$. garvieae should be retained as the species name and strain ATCC 43921 should remain the type strain of this species.
\end{abstract}

The genus Lactococcus was established as a separate genus (distinct from the genus Streptococcus) in 1985 (12). The members of this genus, which formerly were known as the lactic acid group of streptococci, are not usually considered significant pathogens of humans and animals because they are infrequently isolated clinically and are probably associated with opportunistic infections $(1,7,11)$. However, the role of these microorganisms as infectious agents remains unclear since it is difficult to differentiate them from members of physiologically similar genera and to identify them to the species level. It is believed that because they resemble other better-known clinical isolates, especially enterococci, the lactococci may be misidentified or overlooked in clinical laboratories, which contributes to the paucity of reports concerning their clinical significance.

Data for cultures received at the Centers for Disease Control and Prevention indicate that lactococci may be involved in a variety of infections in humans and that the genus Lactococcus should be considered whenever a bacterial isolate resembles an Enterococcus sp. in all but a few characteristics. Lactococcus garvieae is the species that is most frequently isolated from such infections, followed by Lactococcus lactis $(5,7)$. On the other hand, although information concerning animal infections is even more scarce, it should be noted that $L$. garvieae

* Corresponding author. Mailing address: Childhood and Respiratory Diseases Branch, MS-CO2, Centers for Disease Control and Prevention, Atlanta, GA 30333. Phone: (404) 639-1379. Fax: (404) 6393123 . (originally named Streptococcus garvieae in 1983) was described as an organism isolated from an animal with bovine mastitis (3).

In 1991, a new enterococcal species, Enterococcus seriolicida, was described as a fish pathogen (9) on the basis of low levels of DNA relatedness to the type strains of previously described enterococcal species. In 1993, E. seriolicida was found to be similar to $L$. garvieae as determined by $16 \mathrm{~S}$ rRNA sequencing (4), but DNA hybridization studies were not done.

Recently, during a survey of bacterial agents that cause subclinical mastitis in Brazilian water buffalos raised for milk production, we isolated a group of gram-positive cocci that had phenotypic characteristics similar to those of either enterococci or lactococci. These strains accounted for the majority of the bacterial agents isolated in the survey (13a).

The purpose of this study was to determine the identity of the water buffalo mastitis isolates and to determine if $L$. garvieae and $E$. seriolicida are a single species or distinct species.

\section{MATERIALS AND METHODS}

Bacterial strains. A total of 21 strains isolated from water buffalos with subclinical mastitis were studied. The infected animals were members of herds located in the state of Rio de Janeiro, Brazil. Seven type and reference strains (obtained from the culture collection of the Centers for Disease Control and Prevention or from the American Type Culture Collection) representing the species of gram-positive cocci that were physiologically most similar to the clinical isolates were also included in the study (Table 1).

Characterization of strains. Phenotypic characteristics were determined by performing conventional physiologic tests $(6,8)$. These tests included tests for production of pyrrolidonyl arylamidase, leucine aminopeptidase, and gas from glucose in Mann-Rogosa-Sharpe Lactobacillus broth; hydrolysis of esculin in the 
TABLE 1. Characteristics of the strains included in this study

\begin{tabular}{|c|c|c|c|c|c|c|c|c|}
\hline Characteristic & 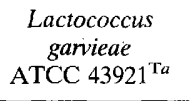 & $\begin{array}{l}\text { Lactococcus } \\
\text { garvieae } \\
\text { SS-1290 }\end{array}$ & $\begin{array}{l}\text { Enterococcus } \\
\text { seriolicida } \\
\text { ATCC } 49156^{\mathrm{T}}\end{array}$ & $\begin{array}{l}\text { Lactococcus } \\
\quad \text { lactis } \\
\text { ATCC } 19435^{\mathrm{T}}\end{array}$ & $\begin{array}{l}\text { Enterococcus } \\
\text { durans } \\
\text { ATCC } 11576\end{array}$ & $\begin{array}{l}\text { Enterococcus } \\
\quad \text { durans } \\
\text { ATCC } 19432^{\mathrm{T}}\end{array}$ & $\begin{array}{c}\text { Enterococcus } \\
\quad \text { hirae } \\
\text { ATCC } 8043^{\mathrm{T}}\end{array}$ & $\begin{array}{c}\text { Clinical } \\
\text { isolates } \\
(n=21)^{b}\end{array}$ \\
\hline $\begin{array}{l}\text { Gas production in Mann- } \\
\text { Rogosa-Sharpe broth }\end{array}$ & - & - & - & - & - & - & - & - \\
\hline Pyrrolidonyl arylamide activity & + & + & + & - & + & + & + & + \\
\hline Leucine aminopeptidase activity & + & + & + & + & + & + & + & + \\
\hline $\begin{array}{l}\text { Hydrolysis of esculin in the } \\
\text { presence of bile }\end{array}$ & + & + & + & + & + & + & + & + \\
\hline $\begin{array}{l}\text { Growth in the presence of } 6.5 \% \\
\mathrm{NaCl}\end{array}$ & $+^{c}$ & $+^{c}$ & + & - & + & + & + & $t^{c}$ \\
\hline Growth at $10^{\circ} \mathrm{C}$ & + & + & + & $t^{c}$ & + & + & + & + \\
\hline Growth at $45^{\circ} \mathrm{C}$ & $+^{c}$ & $+c$ & + & $+^{c}$ & + & + & + & $+c$ \\
\hline Vancomycin susceptibility & + & + & + & + & + & + & + & + \\
\hline Arginine hydrolysis & + & + & + & + & + & + & + & + \\
\hline Hippurate hydrolysis & - & - & - & - & + & - & - & - \\
\hline Pyruvate utilization & - & - & - & - & - & - & - & - \\
\hline Tellurite tolerance & - & - & + & - & - & - & - & V \\
\hline Motility & - & - & - & - & - & - & - & - \\
\hline Pigment production & - & - & - & - & - & - & - & - \\
\hline Voges-Proskauer reaction & + & + & + & + & + & + & + & + \\
\hline \multicolumn{9}{|l|}{ Acid production from: } \\
\hline Arabinose & - & - & - & - & - & - & - & -- \\
\hline Glycerol & - & - & - & - & + & - & - & - \\
\hline Inulin & - & _- & - & - & - & - & - & - \\
\hline Lactose & + & - & - & + & + & + & + & + \\
\hline Maltose & + & + & + & + & + & + & + & + \\
\hline Mannitol & + & + & + & - & - & - & - & - \\
\hline Melibiose & - & - & - & - & - & - & + & - \\
\hline Raffinose & - & - & - & - & - & - & + & - \\
\hline Ribose & + & + & + & + & + & + & + & + \\
\hline Sorbitol & - & - & - & - & - & - & - & - \\
\hline Sorbose & - & - & - & - & - & - & - & - \\
\hline Sucrose & - & - & - & - & - & - & + & - \\
\hline Trehalose & + & + & + & + & + & - & + & + \\
\hline Serogroup & - & - & - & $\mathrm{N}$ & D & D & D & - \\
\hline Enterococcal probe reaction & - & - & - & - & + & + & + & - \\
\hline
\end{tabular}

\footnotetext{
${ }^{a} \mathrm{~T}=$ type strain.

${ }^{b}+$, all strains were positive; -, all strains were negative; $\mathrm{V}, 40 \%$ of the strains were positive.

${ }^{c}$ Delayed on weak reaction.
}

presence of bile; hydrolysis of arginine; hydrolysis of hippurate; growth in broth containing $6.5 \% \mathrm{NaCl}$; growth at 10 and $45^{\circ} \mathrm{C}$; susceptibility to vancomycin; motility; pigment production; pyruvate utilization; tellurite tolerance; the VogesProskauer reaction; and acid production from L-arabinose, glycerol, inulin, lactose, maltose, D-mannitol, melibiose, raffinose, ribose, D-sorbitol, sorbose, sucrose, and trehalose. Serogroups were determined by the Lancefield hot-acid extraction procedure and by capillary precipitation or agar diffusion tests performed with group D and group $N$ antisera. Strains were also tested for reactivity with the AccuProbe Enterococcus culture confirmation test (Gen-Probe, Inc., San Diego, Calif.) as directed by the manufacturer.

Analysis of whole-cell protein profiles by SDS-PAGE. Strains were grown on brain heart infusion-sheep blood plates for $24 \mathrm{~h}$ at $37^{\circ} \mathrm{C}$. Preparation of extracts and analysis of whole-cell protein profiles by one-dimensional sodium dodecyl sulfate (SDS)-polyacrylamide gel electrophoresis (PAGE) were performed as described by Merquior et al. (10). Briefly, bacterial cells were removed from the surfaces of the blood agar plates and suspended in $0.5-\mathrm{ml}$ portions of an aqueous lysozyme solution $(10 \mathrm{mg} / \mathrm{ml})$. The resulting suspensions were incubated in a $37^{\circ} \mathrm{C}$ water bath for $2 \mathrm{~h}$. Whole-cell extracts were obtained by mixing 1 volume of each sample with 1 volume of $0.5 \mathrm{M}$ Tris- $\mathrm{HCl}(\mathrm{pH} 6.8$ ) containing $4 \%$ SDS, $20 \%$ glycerol, and $10 \%$ 2-mercaptoethanol and boiling the preparation for $5 \mathrm{~min}$. Soluble samples were applied to wells in a $4 \%$ acrylamide stacking gel over a $10 \%$ acrylamide separating gel. SDS-PAGE was performed with a Mini Protean II apparatus (Bio-Rad Laboratories, Richmond, Calif.) at a constant current of $20 \mathrm{~mA}$. The whole-cell protein bands were stained with Coomassie brilliant blue R-250.

Protein profiles were compared by using the correlation coefficients to form a similarity matrix and were clustered by the unweighted pair group method with averages by using the Whole Band Analyzer software of the Bio Image Electrophoresis Analyzer System (Bio Image/Millipore Corp., Ann Arbor, Mich.).

DNA relatedness studies. Twelve clinical isolates, as well as the seven enterococcal and lactococcal type and reference strains, were used in DNA relatedness experiments. Each strain was grown in 2 liters of Todd-Hewitt broth at $37^{\circ} \mathrm{C}$ for 18 to $20 \mathrm{~h}$ with gentle shaking. Harvesting and lysis of the bacterial cells were performed as recommended by Teixeira et al. (13). The procedures used to extract and purify the DNA and to determine DNA relatedness by the hydroxyapatite hybridization method were essentially the procedures recommended by Brenner et al. (2). The DNAs were labeled enzymatically with $\left[{ }^{32} \mathrm{P}\right] \mathrm{dCTP}$ by using a nick translation reagent kit (Gibco BRL Life Technologies, Inc., Gaithersburg, Md.), as recommended by the manufacturer. DNA hybridization experiments were performed at $55^{\circ} \mathrm{C}$ for optimal DNA reassociation. Levels of DNA reassociation were also determined at a stringent temperature $\left(70^{\circ} \mathrm{C}\right)$. Levels of divergence for related sequences were determined by assuming that each $1^{\circ} \mathrm{C}$ of heteroduplex instability, compared with the melting temperature of the homologous duplex, was caused by approximately $1 \%$ unpaired bases. Levels of divergence were calculated to the nearest $0.5 \%$.

\section{RESULTS AND DISCUSSION}

The physiologic characteristics of the strains which we studied are shown in Table 1. The isolates obtained from water buffalos with mastitis had similar physiologic profiles. They were positive for pyrrolidonyl arylamidase activity, leucine aminopeptidase activity, hydrolysis of esculin in the presence of bile, hydrolysis of arginine, and the Voges-Proskauer test; growth occurred at $10^{\circ} \mathrm{C}$ and, although the growth was weak and slow, at $45^{\circ} \mathrm{C}$ and in broth containing $6.5 \% \mathrm{NaCl}$. All of the strains produced acid from lactose, maltose, ribose, and trehalose, and none of the strains produced acid from arabinose, glycerol, inulin, mannitol, melibiose, raffinose, sorbitol, sor- 
A

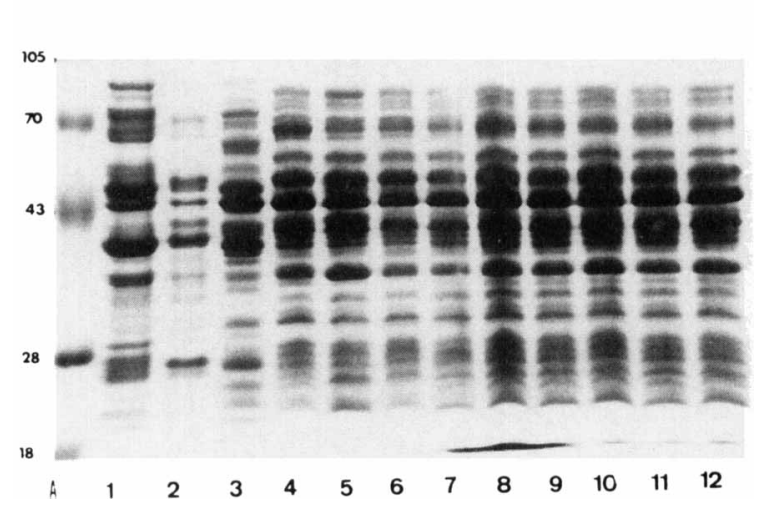

B

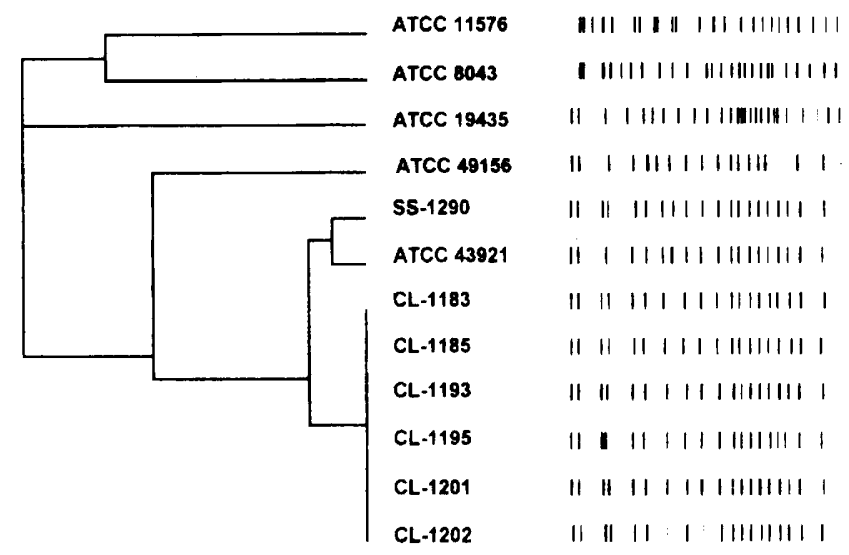

\section{$\underset{71}{74}$}

FIG. 1. (A) SDS-PAGE patterns of whole-cell protein extracts of representative strains used in this study. Lane A, molecular mass markers; lane 1, Enterococcus durans ATCC 11576; lane 2, Enterococcus hirae ATCC 8043 ${ }^{\mathrm{T}}$ ( $\mathrm{T}=$ type strain); lane 3, Lactococcus lactis ATCC $19435^{\mathrm{T}}$; lane 4 , Enterococcus seriolicida ATCC 49156 ${ }^{\mathrm{T}}$; lane 5, Lactococcus garvieae SS-1290; lane 6, Lactococcus garvieae ATCC 43921 ; lane 7, strain CL-1183; lane 8, strain CL-1185; lane 9, strain CL-1193; lane 10, strain CL-1195; lane 11, strain CL-1201; lane 12, strain CL-1202. The numbers on the left indicate the positions of molecular mass markers (in kilodaltons). (B) Dendrogram resulting from a computer-assisted analysis of the protein profiles shown in panel $\mathrm{A}$.

bose, and sucrose. All of the strains were susceptible to vancomycin, nonmotile, and nonpigmented and were negative for production of gas, hippurate hydrolysis, and pyruvate utilization. No strain reacted with either "streptococcal" group D or group $\mathrm{N}$ antisera.

On the basis of the results of the conventional physiologic tests, the most likely identity of these microorganisms was Enterococcus durans, as they were similar to enterococci except that they grew slowly at $45^{\circ} \mathrm{C}$ and in broth containing $6.5 \%$ $\mathrm{NaCl}$. However, none of the strains reacted with the AccuProbe Enterococcus genetic probe. Therefore, we also explored the possibility that these strains were biochemically atypical lactococci, although growth at $45^{\circ} \mathrm{C}$ and growth in the presence of $6.5 \% \mathrm{NaCl}$, especially in conjunction with a failure to produce acid from mannitol and sucrose, are uncommon characteristics for lactococci isolated from humans, which account for most of the data available (7).

An analysis of the electrophoretic whole-cell protein profiles of the water buffalo isolates was performed, and the profiles obtained were compared with the profiles obtained for type and reference strains of the species that are phenotypically most similar to the clinical isolates. Our analysis of whole-cell protein profiles revealed that the water buffalo mastitis strains had virtually indistinguishable profiles that were not similar to the profile of any enterococcal species and, thus, were not likely to belong to the genus Enterococcus. Additional tests showed that, apart from minor quantitative differences, the protein profiles of the water buffalo mastitis isolates were very similar to the profiles of the L. garvieae and E. seriolicida type strains (Fig. 1).

The results of the DNA relatedness experiments were consistent with the results of the protein profile analysis (Table 2). All of the mastitis isolates exhibited species level relatedness to the type strain of $L$. garvieae and low levels of relatedness to the enterococcal strains. All of the mastitis strains conformed to at least two of the following three species level DNA-DNA relatedness criteria (14): a level of relatedness of $70 \%$ or more under optimal conditions (in this study, the levels of relatedness ranged from 63 to $75 \%$ ), a level of divergence of less than $5 \%$ for related sequences (range in this study, 0.5 to $2.5 \%$ ), and a level of relatedness of $60 \%$ or more under stringent conditions (range in this study, 63 to $78 \%$ ). Because the relative binding ratios under the optimal conditions were close to the lowest values recommended for members of a species, we decided to label one of the water buffalo isolates (CL-1202) and determine its levels of relatedness to all other strains. The strains were found to be closely related to each other; the relative binding ratios with CL-1202 ranged from 86 to $100 \%$ (average, 98\%). The results of the DNA relatedness studies, in conjunction with the results of the biochemical tests, indicate that the water buffalo isolates may constitute a unique $L$. garvieae biogroup.

Careful interpretation of tests to determine growth at $45^{\circ} \mathrm{C}$ and growth in broth containing $6.5 \% \mathrm{NaCl}$ is recommended to differentiate between the enterococci, which usually grow well under these conditions, and the lactococci, which usually grow poorly or not at all (7). Serogrouping can also be used to differentiate the enterococci from the lactococci on the basis of the presence of group D and group $\mathrm{N}$ antigens, respectively. However, the water buffalo lactococcal isolates analyzed in this study had very similar physiologic profiles with an unusual combination of characteristics (slow growth at $45^{\circ} \mathrm{C}$ and in broth containing $6.5 \% \mathrm{NaCl}$ and failure to produce acid from mannitol and sucrose) that made them more difficult to properly differentiate and identify. They were phenotypically indistinguishable from the enterococcal species $E$. durans and had characteristics that are not common among human isolates of L. garvieae. In addition, no group $\mathrm{D}$ or $\mathrm{N}$ antigens were detected.

These findings indicate that biochemical variation is possible among strains isolated from sources other than human sources. The original phenotypic description of $L$. garvieae should be broadened to include the variants that grow at $45^{\circ} \mathrm{C}$. Our data also show that it is necessary to use additional methods for 
TABLE 2. Levels of DNA relatedness of physiologically atypical L. garvieae strains isolated from buffalos with subclinical mastitis

\begin{tabular}{|c|c|c|c|c|}
\hline \multirow[b]{2}{*}{ Source of unlabeled DNA ${ }^{a}$} & \multicolumn{3}{|c|}{$\begin{array}{l}\text { Labeled DNA from Lactococcus garvieae } \\
\text { ATCC } 43921^{\mathrm{T} b}\end{array}$} & \multirow{2}{*}{ 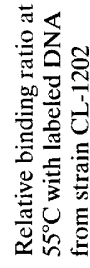 } \\
\hline & 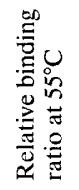 & 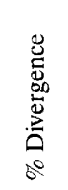 & 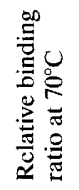 & \\
\hline \multicolumn{5}{|l|}{ Reference strains } \\
\hline Lactococcus garvieae ATCC $43921^{\mathrm{T}}\left(=\mathrm{NCDO} 2155^{\mathrm{T}}=\mathrm{SS}-1270^{\mathrm{T}}\right)$ & 100 & 0.0 & 100 & 77 \\
\hline Lactococcus garvieae SS-1290 & 73 & 1.0 & 75 & 84 \\
\hline Enterococcus seriolicida ATCC $49156^{\mathrm{T}}\left(=\mathrm{SS}-1311^{\mathrm{T}}\right)$ & 77 & 1.0 & 77 & 77 \\
\hline Lactococcus lactis ATCC $19435^{\mathrm{T}}\left(=\mathrm{NTCC} 6681^{\mathrm{T}}=\mathrm{SS}-668^{\mathrm{T}}\right)$ & 14 & 15.0 & & \\
\hline Enterococcus durans ATCC $19432^{\mathrm{T}}\left(=\mathrm{SS}-661^{\mathrm{T}}\right)$ & 3 & 16.0 & & \\
\hline Enterococcus durans ATCC $11576(=$ SS-1225) & 3 & 16.0 & & \\
\hline Enterococcus hirae ATCC $8043^{\mathrm{T}}\left(=\mathrm{NCDO} 1258^{\mathrm{T}}=\mathrm{SS}-1227^{\mathrm{T}}\right)$ & 4 & 12.0 & & \\
\hline \multicolumn{5}{|l|}{ Clinical strains } \\
\hline CL-1183 & 69 & 1.0 & 69 & 95 \\
\hline CL-1185 & 72 & 0.5 & 63 & 100 \\
\hline CL-1192 & 63 & 1.5 & 65 & 86 \\
\hline CL-1193 & 75 & 1.5 & 71 & 96 \\
\hline CL-1195 & 72 & 2.5 & 63 & 100 \\
\hline CL-1197 & 72 & 1.0 & 64 & 100 \\
\hline CL-1201 & 72 & 1.0 & 63 & 99 \\
\hline CL-1202 & 71 & 1.0 & 65 & 100 \\
\hline CL-1203 & 75 & 1.5 & 63 & 99 \\
\hline CL-1206 & 75 & 1.5 & 78 & 100 \\
\hline CL-1207 & 74 & 1.5 & 64 & 100 \\
\hline CL-1208 & 71 & 1.5 & 63 & 97 \\
\hline
\end{tabular}

${ }^{a}$ ATCC, American Type Culture Collection; SS, standard strain from the culture collection of the Centers for Disease Control and Prevention; NCDO, National Collection of Dairy Organisms; NTCC, National Type Culture Collection.

${ }^{b} \mathrm{~T}=$ type strain.

precise identification of such isolates. Enterococcal probe reactions were found to be a useful tool for including or excluding strains from the enterococcal group. Therefore, we recommend that this test be used when bacterial isolates resemble enterococci or lactococci in all but a few characteristics. In addition, electrophoretic whole-cell protein profile analysis was shown to be a reliable and relatively simple method for identifying atypical $L$. garvieae strains.

The high levels of DNA relatedness between strains of L. garvieae and E. seriolicida (77\% under either optimum or stringent conditions, with $1 \%$ divergence) demonstrate that these organisms belong to a single species, as suggested previously on the basis of the results of an analysis of biochemical and protein profiles, as well as $16 \mathrm{~S}$ rRNA sequencing (4). Since $L$. garvieae was described first, $L$. garvieae is a senior subjective synonym of $E$. seriolicida. Therefore, the name $L$. garvieae should be retained, strain ATCC 49156 should be renamed $L$ garvieae, and the type strain of $L$. garvieae remains ATCC 43921 ( = NCDO 2155).

\section{ACKNOWLEDGMENTS}

This study was supported in part by Conselho Nacional de Desenvolvimento Científico e Tecnológico (CNPq), Coordenação de Aperfeiçoamento de Pessoal de Nível Superior (CAPES), and Financiadora de Estudos e Projetos (FINEP), Brazil.

We thank Susan Hunter and Bala Swaminathan of the Centers for Disease Control and Prevention for providing facilities for our computer-assisted analysis and Carlos Ausberto B. de Souza of the Instituto de Microbiologia, Universidade Federal do Rio de Janeiro, for technical assistance.

\section{REFERENCES}

1. Aguirre, M., and M. D. Collins. 1993. Lactic acid bacteria and human clinical infection. J. Appl. Bacteriol. 75:95-107.

2. Brenner, D. J., A. C. McWhorter, J. K. Leete Knutson, and A. G. Steigerwalt. 1982. Escherichia vulneris: a new specics of Enterobacteriaceae associated with human wounds. J. Clin. Microbiol. 15:1133-1140.

3. Collins, M. D., J. A. E. Farrow, B. A. Phillips, and O. Kandler. 1983. Streptococcus garvieae sp. nov. and Streptococcus plantarum sp. nov. J. Gen. Microbiol. 129:3427-3431.

4. Domenech, A., J. Prieta, J. F. Fernandez-Garayzabal, M. D. Collins, D. Jones, and L. Dominguez. 1993. Phenotypic and phylogenetic evidence for a close relationship between Lactococcus garvieae and Enterococcus seriolicida. Microbiol. Sem. 9:63-68.

5. Elliot, J. A., M. D. Collins, N. E. Pigott, and R. R. Facklam. 1991. Differentiation of Lactococcus lactis and Lactococcus ganieae from humans by comparison of whole-cell protein patterns. J. Clin. Microbiol. 29:2731-2734.

6. Facklam, R. R., and M. D. Collins. 1989. Identification of Enterococcus species isolated from human infections by a conventional test scheme. J. Clin. Microbiol. 27:731-734.

7. Facklam, R. R., and J. A. Elliot. 1995. Identification, classification, and clinical relevance of catalase-negative, gram-positive cocci, excluding the streptococci and enterococci. Clin. Microbiol. Rev. 8:479-495.

8. Facklam, R. R., and D. F. Sahm. 1995. Enterococcus, p. 308-314. In P. R. Murray, E. J. Baron, M. A. Pfaller, F. C. Tenover, and R. H. Yolken (ed.), Manual of clinical microbiology, 6th ed. American Society for Microbiology, Washington, D.C.

9. Kusuda, R., K. Kawai, F. Salati, C. R. Banner, and J. L. Fryer. 1991. Enterococcus seriolicida sp. nov., a fish pathogen. Int. J. Syst. Bacteriol. 41: 406-409.

10. Merquior, V. L. C., J. M. Peralta, R. R. Facklam, and L. M. Teixeira. 1994. Analysis of electrophoretic whole-cell protein profiles as a tool for characterization of Enterococcus species. Curr. Microbiol. 28:149-153.

11. Ruoff, K. L. 1995. Leuconostoc, Pediococcus, Stomatococcus, and miscellaneous gram-positive cocci that grow aerobically, p. 315-323. In P. R. Murray, E. J. Baron, M. A. Pfaller, F. C. Tenover, and R. H. Yolken (ed.), Manual of clinical microbiology, 6th ed. American Society for Microbiology, Washington, D.C.

12. Schleifer, K. H., J. Klaus, C. Dvorak, R. Kilpper-Balz, M. D. Collins, and W. 
Fischer. 1985. Transfer of Streptococcus lactis and related streptococci to the genus Lactococcus gen. nov. Syst. Appl. Microbiol. 6:183-195.

13. Teixeira, L. M., R. R. Facklam, A. G. Steigerwalt, N. E. Pigott, V. L. C. Merquior, and D. J. Brenner. 1995. Correlation between phenotypic characteristics and DNA relatedness within Enterococcus faecium strains. J. Clin. Microbiol. 33:1520-1523.
13a.Vianni, M. C. E., et al. Unpublished data.

14. Wayne, L. G., D. J. Brenner, R. R. Colwell, P. A. D. Grimont, O. Kandler, M. I. Krichevsky, L. H. Moore, W. E. C. Moore, R. G. E. Murray, E. Stackebrandt, M. P. Starr, and H. G. Trüper. 1987. Report of the Ad Hoc Committee on Reconciliation of Approaches to Bacterial Systematics. Int. J, Syst. Bacteriol. 37:463-464. 